\title{
A DIMENSÃO POLÍTICA DA JURISDIÇÃO CONSTITUCIONAL*
}

\author{
INOCÊNCIO MÁRTIRES COELHO**
}

Já se disse praticamente tudo sobre a jurisdição constitucional, seja para defendê-la, seja para criticá-la. Para o bem ou para o mal, não podemos viver sem ela, pelo menos enquanto não descobrirmos alguma fórmula mágica que nos permita juridificar a política sem ao mesmo tempo, e em certa medida, politizar a justiça. Se o Estado é a forma por excelência de manifestação do poder político e a Constituição o seu estatuto fundamental, então onde quer que se institucionalizem relações de mando, alguém terá que arbitrar-lhes os inevitáveis conflitos. Relembrando palavras de Radbruch, diríamos que se ninguém tem condições de dizer o que é justo, alguém tem que decidir o que é jurídico, até porque a esta altura parecem incogitáveis o abandono do Estado de Direito e o retorno à lei do mais forte.

De outra parte, como se sabe, todo sistema jurídico é duplamente finito, porque não regride sem parar, nem progride indefinidamente. Num extremo, a norma fundamental, no outro a coisa julgada, a fecharem o sistema por necessidade lógica e mesmo axiológica. Logicamente, porque não seria concebível a sua construção sem começo, nem fim; do ponto de vista axiológico, porque sem um mínimo de segurança e de previsibilidade quanto ao desfecho dos conflitos existenciais, seria de todo impossível a convivência humana.

Visto o ordenamento jurídico sob essa perspectiva - que em nada impede se concebam as constituições modernas como sistemas abertos de regras e princípios, que se expandem e se arejam em sempre renovadas concretizações - a opção fundamental reside em sabermos a quem e como atribuir a última palavra sobre o sentido e o alcance das normas do sistema, uma escolha que é politicamente dramá-

* Palestra proferida na VII Semana Jurídica da Faculdade de Direito da UnB, em 6.6.01.

** Prof. de Direito Constitucional. Advogado

R. Dir. Adm.,

Rio de Janeiro, 225: 39-44, jul./set. 2001 
tica até porque, ao fim e ao cabo, o poder de interpretar envolve, também e de fato, o poder de legislar.

A propósito, como dizia o bispo Hoadly, o verdadeiro legislador é aquele que dispõe de autoridade absoluta para interpretar qualquer direito, escrito ou falado, e não aquele que primeiro o redigiu ou enunciou, uma opinião de resto bem próxima daquela externada por Thomas Hobbes, para quem o legislador não é o autor material da lei, em virtude de cuja autoridade ela foi posta em vigor, mas aquele por cuja autoridade ela continua a ser lei.

Pois bem, se isso tudo é verdadeiro - e a história parece não desmentir esses dois pensadores - então aquela op̧̧ão radical deve ser feita com base na própria experiência política, a exemplo do que aconteceu na fundação da república norteamericana, quando os federalistas tudo fizeram para demonstrar que, à luz da experiência histórica, as liberdades públicas e os direitos individuais estariam mais protegidos se ao menos implicitamente deixassem a cargo do Judiciário, e não dos demais poderes do Estado, a prerrogativa excepcional de emitir a última palavra sobre o sentido a sua constituição. E tão naturalmente conseguiram convencer os seus concidadãos quanto ao acerto da fórmula proposta - relembrem-se as palavras de Marshall em Marbury v. Madison - que até hoje, ressalvada a opinião de alguns teimosos, quase todos concordam com Charles Hughes - que foi Governador do Estado de Nova York e, depois, membro da Suprema Corte dos Estados Unidos em dizer que os americanos vivem sob uma constituição, mas essa carta política é aquilo que os seus juízes entendem que ela é.

Exageros à parte, trata-se de uma realidade que decorre não apenas da peculiar estrutura das normas constitucionais - especialmente daquelas em que se definem e protegem os direitos fundamentais - , mas também e sobretudo da natureza e das funções inerentes às cortes constitucionais.

Inicialmente, relembremos, com Mauro Cappelletti, que essas cortes situam-se fora e acima da tradicional tripartição dos poderes estatais, não podendo ser enquadradas nem entre os órgãos jurisdicionais, nem entre os legislativos, nem muito menos entre os órgãos executivos estatais. É que, prossegue o mestre italiano, a elas pertence de fato uma função autônoma de controle constitucional, que não se identifica com nenhuma das funções próprias de cada um dos três poderes tradicionais, mas que incide de várias formas sobre todos eles, para reconduzi-los, quando necessário, à rigorosa obediência às normas constitucionais.

A toda evidência, essa arbitragem consubstancia prerrogativa essencialmente política - de nítido teor constituinte, aliás - porque, embora disfarçadas em trajes hermenêuticos, essas novas leituras da constituição, a que chamamos de mutações constitucionais, implicam também novas tomadas de decisão, com eficácia erga omnes e efeito vinculante, sobre os espaços que, a critério dos juízes e não dos eventuais contendores, as cortes constitucionais venham a considerar próprios de cada poder do Estado.

De outra parte, e para complicar as coisas um pouco mais, a maior parte das normas com que trabalham essas cortes soberanas - os principios constitucionais - , diferentemente dos preceitos jurídicos em geral, apresentam-se em fórmulas lapidares, numa linguagem tão aberta, indeterminada e plurissignificativa, que o ato 
de concretizá-las a rigor não conhece limites e só com extrema boa vontade - à Konrad Hesse, por exemplo - ainda se pode chamar de interpretação. Daí a crítica, sempre repetida, de que em verdade essas cortes, que não dispõem de legitimidade para tanto, acabaram se transformando em terceira câmara dos parlamentos, em verdadeiras constituintes de plantão, como dizem os seus opositores mais ferrenhos. Mais ainda, os próprios métodos e princípios da interpretação constitucional, de contornos indefinidos, como que potencializam essa abertura e essa liberdade, e em tão larga medida, que não cometeríamos exagero se disséssemos que inclusive nesse terreno, aparentemente imune a voluntarismos, também aí o sujeito pode manipular o objeto. Afinal de contas, para que servem, concretamente, expressões tais como unidade da constituição, concordância prática, exatidão funcional ou máxima efetividade, com que se rotulam os diferentes princípios da hermenêutica constitucional, se também elas estão sujeitas a conflitos de interpretação?

Por isso é que, nos Estados Unidos, diante da latitude do seu texto constitucional e da enorme liberdade de interpretação daí decorrente, figuras como Alexander Pekelis chegaram a dizer que, em certo sentido, o país não tinham uma constituição escrita. São desse importante jurista as palavras a seguir, que se tornaram clássicas em tema de interpretação constitucional:

“Devemos recordar que em certo sentido os Estados Unidos não têm uma constituição escrita. As grandes cláusulas da Constituição americana, assim como as disposições mais importantes das nossas leis fundamentais, não contêm senão um apelo à honestidade e à prudência daqueles a quem é confiada a responsabilidade da sua aplicação. Dizer que a compensação deve ser justa; que a proteção da lei deve ser igual; que as penas não devem ser nem cruéis nem inusitadas; que as cauções e as multas não devem ser excessivas; que as investigações ou as detenções hão de ser motivadas; e que a privação da vida, da liberdade ou da propriedade não se pode determinar sem o devido processo legal, tudo isso outra coisa não é senão autorizar a criação judicial do direito, e da própria Constituição, pois a tanto eqüivale deixar que os juízes definam o que seja cruel, razoável, excessivo, devido ou talvez igual."

Para ilustrar essa liberdade de (re)elaboração constitucional, relembremos que entre nós, não faz muito tempo, por decisão expressa do legislador - Leis $\mathbf{n}^{\circ} \mathrm{s}$ 9.868/99 e 9.882/99 - conferiu-se ao STF a prerrogativa excepcional de graduar os efeitos das suas declarações de inconstitucionalidade e de descumprimento de preceito fundamental da constituição, sempre que, a juízo da corte, razões de segurança jurídica ou de excepcional interesse social - conceitos abertos a mais não poder - justifiquem a sobrevida, ainda que temporária e anômala, de atos ou normas incompatíveis com a constituição, uma prerrogativa evidentemente política, mas nem por isso desprovida de razoabilidade, como registramos em estudo dedicado ao tema.

Em suma, quando se afirma que o sentido dessas constituições, conquanto se deva presumir objetivo, em verdade é aquele fixado pelas cortes constitucionais, o que se está a dizer é que nesses sistemas jurídicos, porque os os tribunais constitu- 
cionais (i) trabalham com fórmulas lapidares ou enunciados abertos e indeterminados, quais os que definem os direitos fundamentais nas constituições modernas; (ii) estão situados fora e acima da tradicional tripartição dos poderes estatais; e ( iii ) desfrutam de singular autoridade, os seus juízes, como intérpretes finais da constituição acabam positivando ou constitucionalizando a própria concepção de justiça - rigorosamente a sua ideologia - que outra não é senão aquela da classe social, hegemônica, que eles integram e representam.

No Brasil, há precisos sessenta anos, Francisco Campos expressou opinião semelhante, ao discursar na solenidade de abertura dos trabalhos do STF, em 2 de fevereiro de 1941:

“Juiz das atribuições dos demais Poderes, sois o próprio juiz das vossas. $\mathrm{O}$ domínio da vossa competência é a Constituição, isto é, o instrumento em que se define e se especifica o Governo. No poder de interpretá-la está o de traduzi-la nos vossos próprios conceitos. Se a interpretação, e particularmente a interpretação de um texto que se distingue pela generalidade, a amplitude e a compreensão dos conceitos, não é operação puramente dedutiva mas atividade de natureza plástica, construtiva e criadora, no poder de interpretar há de incluir-se, necessariamente, por mais limitado que seja, o poder de formular. $O$ poder de especificar implica margem de opção tanto mais larga quanto mais lata, genérica, abstrata, amorfa ou indefinida a matéria de cuja condensação há de resultar a espécie."

$\mathrm{Na}$ Alemanha - após destacar a proximidade que existe entre as tarefas da jurisdição constitucional e as funções de direção e configuração políticas - Konrad Hesse assinala que essa jurisdição extraordinária tem de decidir de questões com teor e alcance políticos em número muito maior do que as afetadas às jurisdições ordinárias; que as suas decisões podem acarretar consequiências políticas de grande monta; que, muitas vezes, elas se avizinham de decisões políticas, na medida em que, regularmente, podem ser tomadas com base em critérios amplos e indeterminados da constituição; e que, enfim, a execução das suas decisões é de todo distinta do modo como se executam as decisões das demais jurisdições.

Dado o possível déficit de legitimidade democrática inerente a esse monopólio judiciarista de interpretação autêntica da constituição - uma carência congênita que, evidentemente, não se compensa nem mesmo apelando às melhores criações judiciais do direito - diante disso tudo ganham relevo esforços compensadores, como os de Peter Häberle, que propugna por uma visão republicana e democrática da interpretação constitucional, uma fórmula jurídico-política centrada na tese de que uma sociedade aberta exige uma interpretação igualmente aberta da sua carta política, até porque "no processo de interpretação constitucional estão potencialmente vinculados todos os órgãos estatais, todas as potências públicas, todos os cidadãos e grupos, não sendo possível estabelecer-se um elenco cerrado ou fixado com numerus clausus de intérpretes da Constituição".

Nessa direção, observa o mesmo Häberle que a teoria da interpretação constitucional, durante muito tempo, esteve vinculada a um modelo de interpretação de 
uma sociedade fechada, concentrando-se primariamente na interpretação constitucional dos juízes e nos procedimentos formalizados, do que resultou empobrecido o seu âmbito de investigação. Por isso, é chegada a hora de uma viragem hermenêutica radical para que a interpretação constitucional - que a todos interessa e a todos diz respeito - seja levada a cabo pela e para a sociedade aberta e não apenas pelos operadores oficiais da Constituição, ainda que institucionalmente a última palavra deva continuar com os órgãos da jurisdição constitucional.

Em suma, se vivemos num Estado de Direito, que se pretende liberal, democrático e social, torna-se imperioso que a leitura da sua Constituição se faça em voz alta e à luz do dia, no âmbito de um processo verdadeiramente público e republicano, do qual participem os diversos atores sociais - agentes políticos ou não - porque, afinal, todos os membros da sociedade política fundamentam na constituição os seus direitos e deveres.

Em estreita ligação com o tema, Alonso García registra o crescente reconhecimento de que a interpretação da Constituição tornou-se o problema central do judicial review e que nas discussões sobre a sua legitimidade, as velhas controvérsias em torno da origem desse poder extraordinário cederam lugar a debates novos, desta feita sobre o método - é jurídico ou político? - de que se utiliza a jurisdição constitucional para dar a última palavra sobre a Constituição, uma preocupação tanto mais legítima quanto sabemos que a escolha do método e o seu manejo, de resto guiados pela pré-compreensão dos juízes, acabam condicionando, senão mesmo determinando, o conteúdo das suas decisões.

De outra parte, não havendo clima para contestações à própria Lei Fundamental - cuja legitimidade ninguém põe em dúvida - parece que os fatores reais de poder, racionalizando as suas disputas, resolveram deslocar, senão todas, pelo menos grande parte das questões políticas para a arena da jurisdição constitucional, uma privilegiada constituinte de plantão onde quem vence o conflito das interpretações vence também aquelas disputas e constitucionaliza as suas opiniões.

Se tivermos presente, igualmente, que a defesa das constituições democráticas é também a defesa dos valores supremos que elas reconhecem e proclamam; e que é muito mais fácil aos grupos minoritários, com uma simples petição, provocar a jurisdição constitucional contra leis que os discriminem do que fazer abaixo-assinados ou gritar palavras de ordem, que via de regra não inibem esses nem outros abusos legislativos; se atentarmos para tudo isso, seremos obrigados a admitir que, nos dias atuais, longe de ser politicamente ilegítima - como a consideram os seus opositores históricos - essa superlegislatura acabará se mostrando instituição política das mais democráticas, como a considera Mauro Cappelletti, em quem recolhemos esta entusiástica defesa da legislação judicial:

“Não há dúvida de que é essencialmente democrático o sistema de governo no qual o povo tem o 'sentimento de participação'. Mas tal sentimento pode ser facilmente desviado por legisladores e aparelhos burocráticos longínquos e inacessíveis, enquanto, pelo contrário, constitui característica quoad substantiam da jurisdição (...) desenvolver-se em direta conexão com as partes 
interessadas, que têm o exclusivo poder de iniciar o processo jurisdicional e determinar o seu conteúdo, cabendo-lhes ainda o fundamental direito de serem ouvidas. Neste sentido, o processo jurisdicional é até o mais participatório de todos os processos da atividade pública."

De outra parte, a própria organização desses tribunais extraordinários - na Alemanha, Itália, França, Espanha e Portugal, por exemplo - demonstra que os instituidores da jurisdição constitucional conceberam-na como instância de avaliação jurídica e também política da atividade legislativa, sem que essa opção implicasse quer a politização da justiça, quer a judicialização da política. Muito ao contrário, mesmo dispondo de ampla liberdade para escolher os seus representantes nessas cortes constitucionais, jamais algum segmento político indicou pessoas desequilibradas ou desqualificadas para exercer essa magistratura suprema.

Nesse amplo contexto, em que os dissídios de interpretação constitucional assumem inevitável conotação política, registre-se que entre nós o quadro não é diferente. Com efeito, pois desde a promulgação da Carta de 1988 até o dia 01.6.01, já foram propostas nada menos que 2.467 ações de inconstitucionalidade, uma estatística evidentemente impressionante mesmo levando-se em conta o extenso rol de agentes legitimados a provocar a jurisdição constitucional, e o natural inconformismo daqueles que, não tendo conseguido viabilizar as suas propostas legislativas ou impedir as dos seus adversários, batem às portas do STF na esperança de reverter decisões que reputam contrárias aos seus interesses.

Mesmo que, na maioria dos casos, essas tentativas se mostrem infrutíferas, até porque não é usual produzirem-se leis inconstitucionais, a simples possibilidade de levar a matéria para um segundo turno de discussão e votação - agora relativamente neutras ou imparciais, porque realizadas fora da arena político-partidária - só isso já tem compelido os grandes blocos parlamentares a negociar com as minorias, cujos direitos não podem ser ignorados por uma errada compreensão do princípio majoritário.

Essa é uma razão a mais, entre tantas outras, para exaltarmos as virtudes dessa jurisdição de eqüidade constitucional e fazermos nossas as palavras de Kelsen e Kimminich, para quem a guarda da Constituição, nos termos em que foi confiada a essa justiça extraordinária, afigura-se indispensável ao aprimoramento do regime democrático e do Estado de Direito. As palavras de Kelsen quando ressaltam que a defesa da Constituição contra leis inconstitucionais representa, também e essencialmente, a defesa das minorias parlamentares contra os abusos legislativos cometidos pelas maiorias ocasionais; as de Kimminich ao nos advertirem que sem a primazia do princípio da constitucionalidade das leis, cuja reafirmação constante está a cargo da justiça constitucional, o Estado de Direito ficaria reduzido a um simples Estado de legalidade.

Por tudo isso - e para concluir - repetimos, com Javier Perez Royo, que a justiça constitucional é o instrumento historicamente mais desenvolvido que se conheceu até hoje para a juridificação da política, uma tarefa que os seus juízes têm desempenhado com raro equilíbrio, apesar e acima das paixões partidárias que, vez por outra, parecem conspirar contra a sua indispensável existência. 